\title{
The Analysis of Logistic Chains from China to the European Union Countries
}

\author{
Vladimír Klapita ${ }^{1 *}$ and Xiquan Liu $^{2}$
}

${ }^{1}$ University of Zilina, Faculty of Operation and Economics of Transport and Communications, Department of Railway Transport. Zilina, Slovak Republic; Email: klapita@fpedas.uniza.sk

${ }^{2}$ Shandong Foreign Trade Vocational College, International Transportation and Logistics Management Department, Qingdao, Shandong Province, China; Email: daniel4china@ gmail.com

\section{*Corresponding Author: Vladimír Klapita}

\begin{abstract}
The article analyzes possibilities of alternative routes of logistics chains between China and Europe. The new routes should shorten up the transportation time and alleviate the current flows through the big European ports, nevertheless, simultaneously, ensure to preserve other qualitative as well as economic parameters.
\end{abstract}

Keywords: Logistics chains, transportation routes, transportation time, European ports, China

\section{Introduction}

Given the current growth of goods transportation from China to the EU countries, especially to Central Europe, it is necessary to look for such transport possibilities which would make the transportation of this relatively large amount of goods fast and reasonably priced, i.e. with a price acceptable to customers.

The existing logistics chains covering the routes from Far East to Europe mostly use a tri-modal transport system involving to a large extent the sea-going transport; nevertheless, these logistic chains feature quite lengthy transportation time periods also resulting in higher transportation prices. The big European ports, especially Rotterdam, Antwerp, Hamburg etc., that serve as hubs for main import material flows to Central Europe, are congested, and further prospects of transportation growth under the current state of infrastructure could well go beyond their capacities, or possibly they could withstand this growth only with notable problems (long waiting times for loading operations, idle times of means of transport etc.).

Setting up, implementation and organization of a logistic chain depends especially on economic factors, therefore it is necessary to identify such ways of transportation which would lead to its lower price and higher speed, naturally keeping the rest of quality parameters of the logistic chain intact $[1,2]$. 


\section{The Analysis of Logistic Chains on the Lines Between China and Europe}

At present majority of the Chinese goods flowing to the EU markets is transported on the main sea route, which leads from the southern ports of China past Singapore, through the Strait of Malacca and the Suez Canal, across the Mediterranean Sea to the big European ports. This maritime route, though, is already congested, and in addition, several key points (especially in the area of Far East) on this transport line have been under control of USA, a fact not much appreciated by China, since in case the USA - China relations deteriorate, these points can be relatively easily blocked [3-5].

\subsection{Current Situation of Logistic Chains from China to Europe}

A part of the transportation flows from China to Europe goes through the Trans-Siberian Railway (hereinafter only as TR), nevertheless, it concerns only relatively small portion of the transportation flows. This transportation alternative excluding the sea-going transport, in many cases seems to be more convenient, namely in terms of price as well as in terms of a shorter time of transportation. More extensive use of this line is precluded by the throughput of the railway transport infrastructure. Due to the growing exports, though, China is forced to seek other alternative routes to Europe [4,6].

The third alternative, which could help partially alleviate the logistic chains leading through the ports, is the transit railway route going from China through Kazakhstan to Europe. Figure 1 (indicatively) illustrates the current transportation routes from China to Europe. The picture (Figure 1and also Table 1) shows indicative distances and transportation times in respect of the given connections leading from the South China ports to the ports of Western Europe [7].

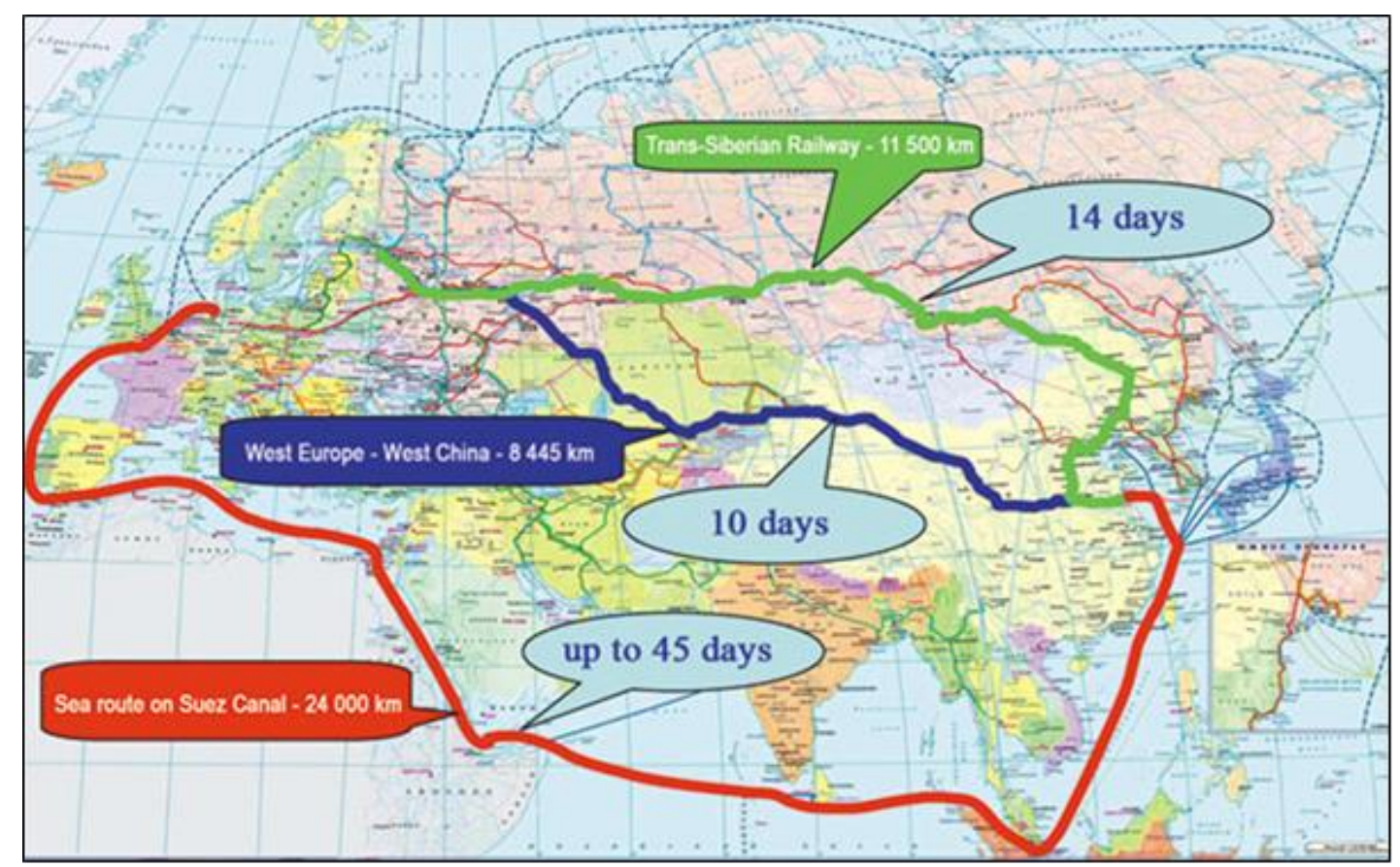

Fig. 1 Main transportation corridors from China to Europe. Source: [7] 
Table 1 Alternative transportation routes from China to Europe. Source: [2,7]

\begin{tabular}{|c|c|c|c|c|}
\hline $\begin{array}{l}\text { Route } \\
\text { No. }\end{array}$ & $\begin{array}{l}\text { Mode of } \\
\text { transport }\end{array}$ & Route & Distance & $\begin{array}{l}\text { Transportation } \\
\text { time }\end{array}$ \\
\hline 1. & Sea & $\begin{array}{l}\text { East China - Shanghai - Suez - } \\
\text { Western Europe }\end{array}$ & $24000 \mathrm{~km}$ & 31 up to 45 days \\
\hline 2. & Railway & $\begin{array}{l}\text { Western China - Kazakhstan - } \\
\text { Russia - Western Europe }\end{array}$ & $8445 \mathrm{~km}$ & 12 up to 14 days \\
\hline 3. & Railway & China - Europe through TR & $11500 \mathrm{~km}$ & 15 up to 19 days \\
\hline
\end{tabular}

The given distances and transportation times are indicative only. The precise transportation distance as well as time and price in respect of the specific logistic chain depend, naturally, on many factors, such as e. g. a geographic position, transport operator etc. In any case it is evident that the transportation on the above lines is considerably shorter and faster $[8,9]$.

\subsection{The Analysis of the Current State of Logistic Chains on the Lines}

The organization of logistic chains is usually in the competence of transportation operators who decide on the route and use of specific modes of transport, or possibly on their convenient combination. The prevailing transport mode between China and Europe will continue to be (also in the future) the water (sea-going) transport, which due to the applied means of transport such as seagoing ships, have a large capacity. The capacity of large sea container ships reaches several thousands of TEU (often also 8 up to 16 thousand $\mathrm{TEU}^{1}$ ).

The existing maritime transportation routes are operated especially from the South China ports to the big European ports, from which they continue by rail or road to Central Europe. Alternative railway transportation corridors, and naturally also the trains, provide much less capacity, representing only a minor percentage. This is also the reason why it is necessary to consider these railway corridors only as just a kind of complement, not substitution of the existing sea routes [10].

The project „Silk Road“, which represents a major overhaul and modernizing of especially the railway transport infrastructure intended to interconnect China with Europe, aims at increasing the capacity of this transport infrastructure and thus also at relieving the sea waterways. The issue in implementing this project is not the money, but rather regional conflicts possibly arising between the transit countries [11-14].

As a solution to the capacity increasing of the China - Europe transportation routes there exist three alternative routes leading by sea and two alternative inland routes by rail. 
The alternative sea routes are the following:

1. „The southern sea route “. The first maritime route does not differ considerably from the original maritime route (see Table. 1, route 1). The only difference is that instead of the gorge below the old British fortress of Singapore the convoys of ships will float through the newly designed canal connecting the South China Sea and the Andaman Sea. Currently, China and Thailand have signed an intergovernmental memorandum on its construction. Preliminary price of the project amounts to 28 billion of dollars and the time to build it was estimated to take about 10 years (see Fig. 2). When opened, the canal should shorten the distance between the Pacific and Indian Oceans to $1200 \mathrm{~km}$, and in addition, a fact not negligible for China, it will eliminate the American control over this section of the route [1,3,15-19].

2. „The eastern sea route “. The second route is also sea-going, but it runs through the Pacific Ocean and another floating channel, which is currently under construction in Nicaragua. The construction works on the „Grand Transoceanic Canal of Nicaragua" for the time being, proceed very slowly, a fact, which China does not mind, since the „east“ route will become topical only upon the eventual participation of Japan (possibly also of South Korea) in the Chinese global project. This route would thus circumvent the Panama Canal, which is under control of USA $[1,2,20]$.

3. „The northern sea route “. The third (maritime) route would be going on sea along the north coast of the Russian Federation (Fig. 2). In spite of the fact that the current capacity of the northern sea route only amounts to about 500 thousand TEU per year, which, when compared with 9,5 million of TEU per year shipped through the „southern“ route seems to be worse, in Beijing the government already negotiates with the Russian government on expanding the capacity of the northern sea route to 3 , or even 4 million TEU. The time horizon of the project also spans up to about 7 - 10 years. Chinese ships have already tested the northern sea route and it has been estimated that when compared to the „South route“, it is shorter by up to $5-10$ days. Nevertheless, there still remains the issue of its all-year-round operation [2,19-21].

\footnotetext{
1 TEU (Twenty Foot Equivalent Unit), equivalent unit of sea 20-foot container ISO 1C
} 


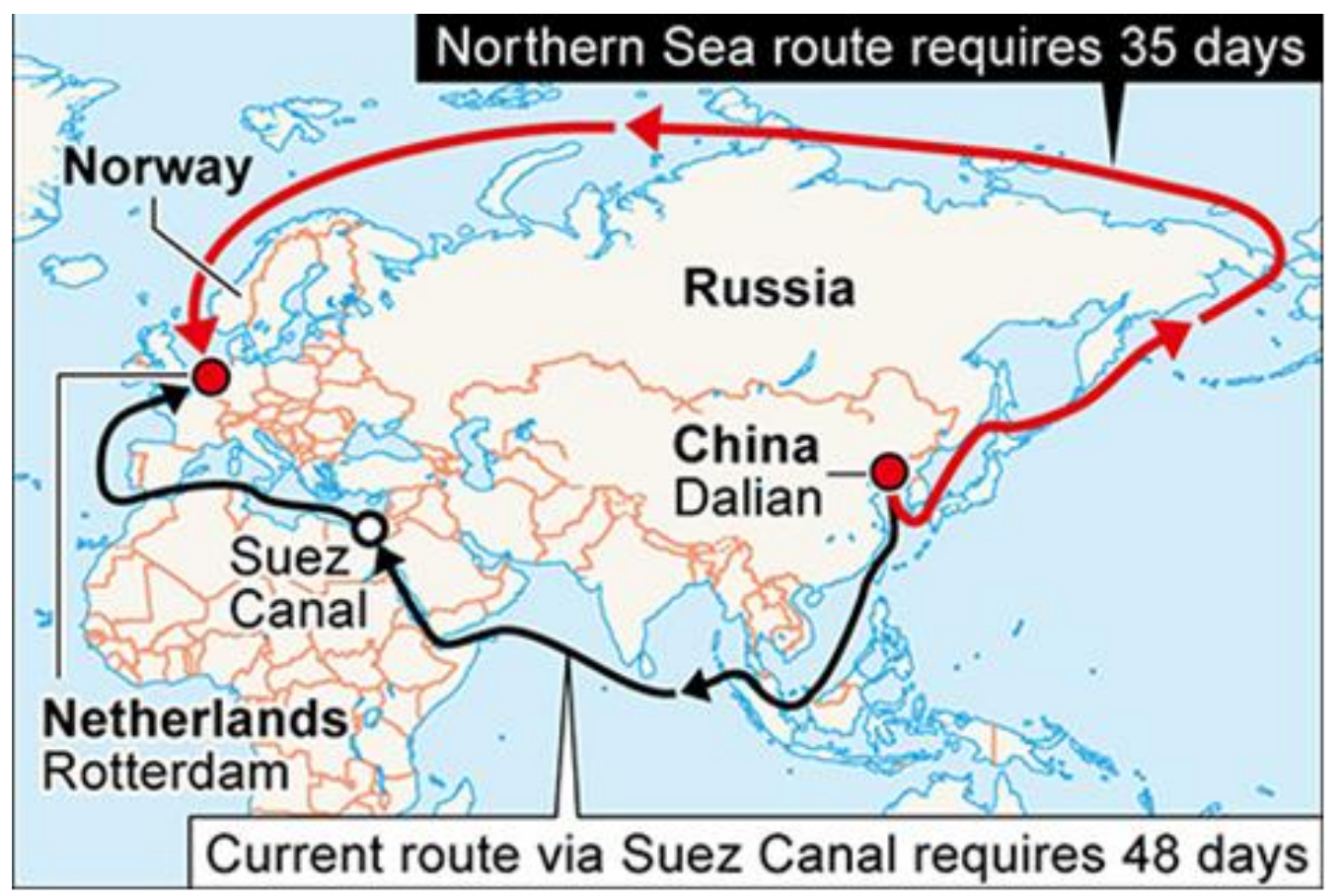

Fig. 2 The northern and southern sea routes. Source: [12]

As an alternative to the maritime logistic routes on the China - Europe transportation lines there are two railway corridors. The alternative railway routes are the following:

1. „The northern variant" considers connecting to the Trans-Siberian Railway. This northernmost variant runs through central China, Mongolia and farther on through the TransSiberian Railway, to the west of Moscow, from where there are two possible branches. The first one leads to the Baltic ports in Leningrad area, from which the goods can be transported by sea to Germany (Cuxhaven port). The second branch leads also to Germany, but this time on land through Belarus and Poland. In comparison with other alternatives this possibility includes a minimum number of border crossings and also presents a development opportunity for less developed areas of China [11].

2. "The central variant“ is currently the most discussed one. The route goes through Kazakhstan and Russia, and then to Belarus and Poland, eventually terminating in Germany. This variant is shorter and the corridor crosses only three borderlines [3, 4]. A comparison of the railway corridors (the northern and central variants) has been presented in Figure 3. 


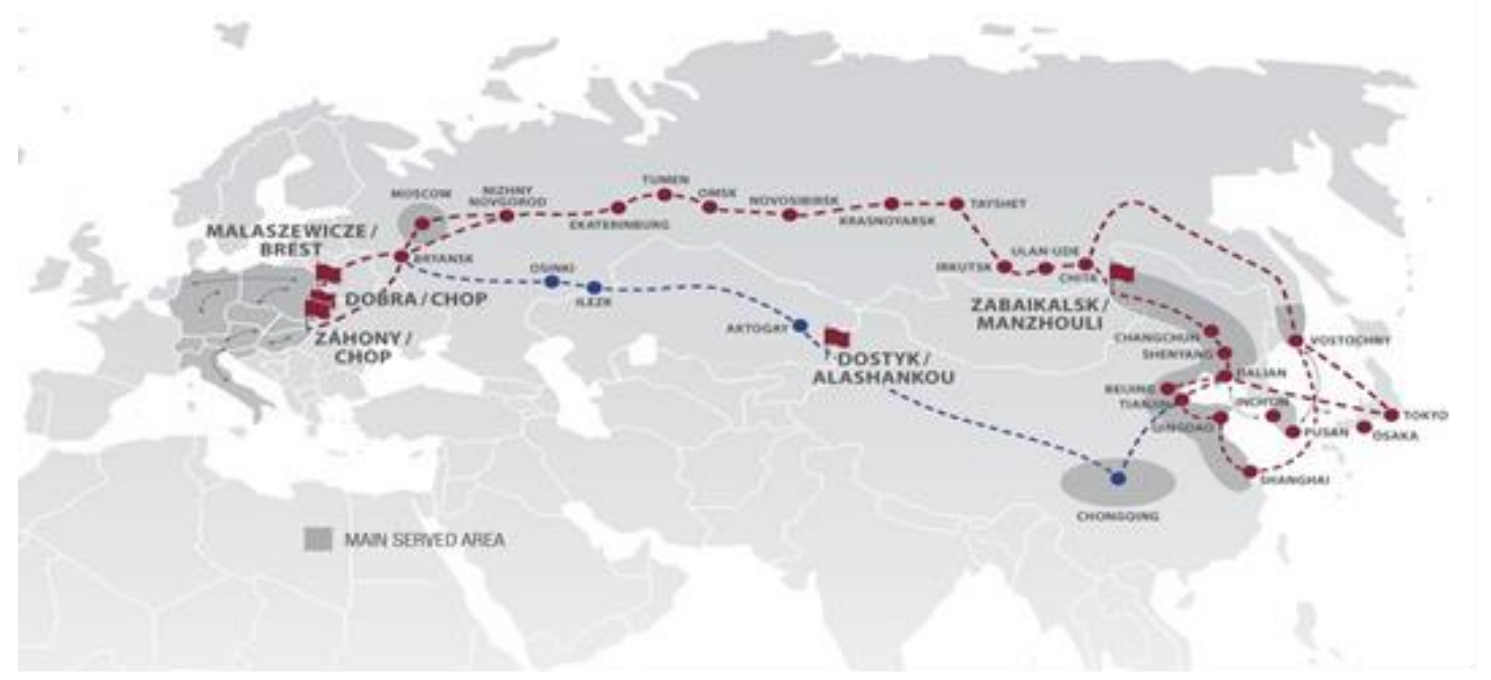

Fig. 3 The northern and central variants of the railway transport corridors. Source: [9]

In addition to the two already mentioned variants there is also the third variant, the so-called „southern variant", in which case the route would lead across Pakistan to the port of Karachi, where the goods would be transloaded on to ships and then shipped farther by sea through the Suez Canal to Italy. This would thus be already a combination of rail and water transport.

Naturally, there also exist other possibilities, nevertheless, they are a bit more complex and in practice hardly practicable. For example, a route through Pakistan, continuing on land through Iran and Turkey to the railway tunnel under the Bosporus and Dardanelles exiting to EU and southern Europe [5].

\section{Conclusion}

When planning a logistics chains it is necessary to seek a solution that is efficient, i.e. ensuring transportation, which is possibly fast and cheap. In case of transportation of a relatively big amount of goods from China to Europe, the sea transport on large capacity container ships will continue to be the major way of transportation; nevertheless, the alternative routes on land by rail represent in many cases a very convenient alternative.

The topic of managing and organizing the logistic chains, especially when it concerns more distanced locations, is not simple and when selecting a suitable transportation route one has to consider all the circumstances. The given solution options of the China - Europe logistic chains alternative routes management and organization that are based on shifting a part of the load from the existing sea routes to the alternative routes (rail and sea), will have to become a reality in the near future and every transportation operator should reflect on his possibilities and use his strengths in these options organization. 


\section{Acknowledgement}

The paper was supported by the VEGA Agency, Grant No. 1/0019/17 "Evaluation of regional rail transport in the context of regional economic potential with a view to effective use of public resources and social costs of transport", at Faculty of Operations and Economics of Transport and Communication, University of Žilina, Slovakia.

\section{References}

[1] Dolinayova, A. (2017). Evaluation of regional rail transport in the context of regional economic potential with a view to effective use of public resources and social costs of transport. Research grant No. 1/0019/17, Faculty of Operations and Economics of Transport and Communication, University of Zilina, Slovakia.

[2] Kalman, S. \& Fotitkar, O. (2014). Nungary - China rilway transportation. Retrieved March 14, 2018, from http://www.binx.ktenet.hu/rendezvenyek/tagozati/2014-02-07_VT_transzkontaruszallitas.

[3] Huo, F, Harrison, A., Jia, F. \& Qi, E.S. (2009). Innovation in Logistics: China-Europe Supply Chains. In ICOSCM 2009 - Proceedings of the $3^{\text {rd }}$ international conference on operations and management, 28. Jul - 5. August 2009 (pp. 438-444). Wuhan, Peoples R China: Chinese univ. Hong Kong, Economics \& Management school, Wuhan univ., Supply chain management research center, Li \& Fung inst. Supply chain management \& Logistics, Wuhan.

[4] Bo, Y. \& Zhu, X.N. (2013). Container Multimodal Transport Based On Railway-water Combined Transportation Coordination: A Case of China. In 2th Wuhan International Conference on E-Business, 25.-26. May (pp. 699-706). Wuhan, Peoples R China: Alfred univ., One Saxon Dr., Alfred, NY 14802 USA.

[5] Dunajskyvedomostnyklaster.eu - portal. Retrieved March 14, 2018, from http://www.dunajskyvedomostnyklaster.eu.

[6] Seo, Y.J., Chen, F.L. \& Roh, S.Y. (2017). Multimodal Transportation: The Case of Laptop from Chongqing in China to Rotterdam in Europe. Asian journal of shipping and logistics, 33(3), 155-165. DOI: 10.1016/j.ajsl.2017.09.005.

[7] Chen, X., Zhu, X.N., Zhou, Q.J. \& Wong, I.D. (2017). Game-Theoretic Comparison Approach for Intercontinental Container Transportation: A Case between China and Europe with the B\&R Initiative. Journal of advanced transportation. Article Number: UNSP 3128372. DOI: 10.1155/2017/3128372. 
[8] Turezhanova, M. (2013). Major Transport Corridor to Connect Kazakhstan. Russia, China by 2015. The Astana Times. 20.2. 2013.

[9] Port of Hamburg. (2017). Retrieved March 14, 2018, from http://www.hafen-hamburg.de

[10] Nozicka, J. (2016). Development of railway transportation between China and the European Union countries. In International Scientific Conference on Knowledge for Market Use 2016 Our Interconnected and Divided World, 8.-9. September (pp. 324-333). Olomouc, Czech Republic: Societas Scientiarum Olomucensis II, Krizkovskeho 10, Olomouc, 77900, Czech Republic.

[11] Turezhanova, M. (2013). Major Transport Corridor to Connect Kazakhstan, Russia, China by 2015. Retrieved March 14, 2018, https://astanatimes.com/2013/02/major-transport-corridorto-connect-kazakhstan-russia-china-by-2015-2/.

[12] Klapita, V. (2017). Analysis of transportation from China to the European Union. In Logistics - Economics - Practice. International scientific conference, December 2017, Žilina, Slovakia.

[13] Port of Rotterdam. (2017) Retrieved March 14, 2018, from http://www.portofrotterdam.com/en/Brochures/portstatistics.

[14] Liu, Z.Y. \& Li, Q. (2002). Measures to promote railway container transportation in China. In 3rd International Conference on Traffic and Transportation Studies (ICTTS 2002), 23.-25. 2002 (pp. 413-418). Gulin, Peoples R China: Amer. Soc. Civil engineers, United engineering center, 345 E 47th st, New York, NY 10017-2398 USA.

[15] Yang, J.D. (2015). Transportation, Boarding, Lodging, and Trade along the Early Silk Road: A Preliminary Study of the Xuanquan Manuscripts. Journal of the American oriental society, 135(3), 421-432. DOI: 10.7817/jameroriesoci.135.3.421.

[16] Ministry of Transport and Construction of the Slovak Republic. (2018). Retrieved March 14, 2018, from http://www.telecom.gov.sk/index/index.php.

[17] Wang, Y.C., Ru, Y.H., Jia, T., Chen, Q. \& Wang, M.Y. (2008). Research on the Standardization of Container Transportation Based on Integration in China. In IEEE/SOLI'2008: Proceedings of 2008 IEEE International conference on service operations and logistics, and informatics, Vol. 1 a 2, 12. - 15. October 2008. Beijing Jiaoton University, Beijing, Peoples R China: IEEE, 345 E 47th st, New York, NY 10017 USA. 
[18] International Transport Journal. (2014). Retrieved March 14, 2018, from http://www.transportjournal.com/de/home/news/artikeldetail/ktz-express-hong-kong-plansnew-rail-freight-services.html.

[19] Bai, Z.L., Wang, H. \& Qi, Y.J. (2001). Comparison among the railway transportation system reform modes in Europe, Japan, the USA etc, and a study of what lessons they can afford the railway system reform in China. In Proceedings of the 2001 International conference on management science and engineering, 18.-20. August 2001 (pp. 2489-2496). Harbin, Peoples R China: Harbin institute technology publishers, 16 Fuxingjie Nangangagqu, Harbin, 150006, Heilongjiang.

[20] Huang, Y.H., Zhou, L.Y. \& Zhou, D.W. (2005). Decision model of the container transportation modes between China's hinterland and harbors. In 6th Conference of the Eastern-Asia-Society-for-Transportation-Studies, 21.-24. September (pp. 32-45). Bangkok, Thailand: Eastern Asia soc. Transportat. studies, C/O Assoc. planning \& Transport at studies, K-Wing 6F, 2-1, Ko Jimachi 5 Chome, CHiyoda-KU, Tokyo, 102-0083, Japan.

[21] Lu, Y., Wu, G. \& Hu, S. (2016). Drying-wetting cycles facilitated mobilization and transport of metal-rich colloidal particles from exposed mine tailing into soil in a gold mining region along the Silk Road. Environmental Earth Sciences, 75(12), 1031-1031. DOI: $10.1007 / \mathrm{s} 12665-016-5812-1$. 